\title{
One-Dimensionality and the Possibility of Utopia. The Contribution of Herbert Marcuse to a Transformation of the Present
}

\author{
Rainer Winter \\ Alpen Adria-Universitaet Klagenfurt, Klagenfurt, Austria
}

\section{Introduction}

Taking the One-Dimensional Man as a starting point, I would like to show in the following what an important contribution the work of Herbert Marcuse can make to a critical theory of the present. More than 50 years after its first publication, this book seems more relevant than ever. It allows us to understand how domination is exerted and maintained in late capitalism that is today organized according to neoliberal principals. It also allows us to ask if there can be alternatives to this society. To date, one-dimensionality has proven itself to be a relevant basic concept of critical theory that first of all analyses society critically as it is by revealing the forces that sustain, legitimize and stabilize the existing structures. However, critical theory is primarily interested in those forces that can negate and subversively circumvent the system and can contribute to emancipation. Therefore, Marcuse thought dialectically, criticizing late capitalistic society from the background of unrealized utopian possibilities and seeking escape routes. His central theme from the thirties to the end of his life was the question of how liberation can be made possible and a utopian condition can be realized that stands beyond the oppression of the given order.

This questioning is, however, no longer central in more recent critical theory. For example, Jürgen Habermas scarcely mentioned Marcuse and his utopian vision in Theory of Communicative Action, which was published two years after Marcuse's death, although he knew his work well (cp. Habermas et al.). Instead, he develops a model of communicative understanding as a new basis of critical theory. Communicative rationality is formally defined. It follows procedures. However, there is no more space in his approach for the power of negativity, which Marcuse and also Adorno felt committed to. Saying this, however, in Habermas a decisive dimension of critical theory is lost which still has a place in social reality today. For example, transnational social movements, that link the use of digital technologies with street protests, challenge corporate capitalism and call for a utopian alternative (Juris, Winter, Widerstand). Besides, a form of politics is further developed in the field of aesthetics that transcends the one-dimensionality of everyday life as well by highlighting the utopian promise of the aesthetic form (Rancière, Politics).

Rainer Winter, Professor of Media and Cultural Theory since 2001 and Head of the Institute of Media and Communications at Alpen Adria-Universitaet Klagenfurt in Austria; Chair of the Section "Sociology of Media and Communications" of the German Society of Sociology. 
In order to view these connections more closely and to show how important Marcuse's critical theory is for an analysis of the present, I will firstly discuss the relationship between liberation and one-dimensionality in his work (2). Then I will show that one-dimensionality shapes the social life of the present (3). By discussing central aspects of Habermas's work, I will make the case for maintaining a dialectical perspective because it gives the chance to criticize one-dimensionality and to strive for a radical transformation of society (4). In current examples from social movements and from the field of aesthetics, I will show how one-dimensionality can be challenged and overcome (5). A short conclusion follows on the relevance of Marcuse's critical theory (6).

\section{The Relationship Between Liberation, Utopia and One-Dimensionality in the Work of Herbert Marcuse}

In my view, the fascination and the uniqueness of Marcuse's work lies in the central theme of emancipation. Although Marcuse makes the structures of domination in advanced industrial society in their stability, their apparent insurmountable form and in their power of integration quite clear, at the same time he points out that, in the face of economic productivity and social richness, a qualitative change, another world, an utopia is imaginable. According to Marcuse, human liberation is possible in late capitalism, but its system consisting of technical, political and economic apparatuses has negated this perspective successfully and effectively until today.

Already in The Concept of Essence (“ZumBegriff des Wesens”), Marcuse differentiated, following Hegel, between essence, the potential of hidden possibilities, and appearance, the actual reality. "[...] At the state of human development we have reached, there are real opportunities for a fulfillment of human life in all areas which are not realised in the present form of social life processes" ${ }^{\text {. }}$. Marcuse states a "tension between the potential and the existing, between what humans and things can be and what they actually are"2. In this way, potentially liberating tendencies exist within the social process but must not be being realized. Thus, Marcuse claims "The care for the human being stands at the center of the theory; he should be liberated from real emergency and from real misery and should realize himself"3. Here it becomes clear that for Marcuse dialectical thinking has a negating or emancipatory power. This seeks not only to understand or interpret the world, but rather to contribute to its transformation and to realize utopian demands. Positivism on the other hand is content with an understanding of the "facticity of appearances" and so perseveres with one-dimensionality.

In One-Dimensional Man, one-dimensionality emphatically becomes a historical concept. In advanced industrial society or in late capitalism, the emancipatory power of intrinsic negation has been lost. The proletariat, the revolutionary subject in the work of Marx, is also integrated into the repressive system of domination. This process has advanced so far that the proletariat has even become a carrier of the system. The economic, technical and political apparatuses have successfully neutralized its inner negation. The possibility of liberation no longer seems to be given. Alternatives or potentialities that could overcome the existing system

\footnotetext{
1 “(...) auf dem erreichten Stadium der Entwicklung der Menschheit sind reale Möglichkeiten einer Erfüllung des menschlichen Lebens in allen Bereichen vorhanden, die durch die gegenwärtige Form des gesellschaftlichen Lebensprozesses nicht verwirklicht werden” (Marcuse, Begriff des Wesens, p. 71).

2 "Die Spannung zwischen dem Seinkönnenden und dem Daseienden, zwischen dem, was der Mensch und die Dinge sein können, und dem, was sie faktisch sind, ist einer der zentralen Hebel der Theorie” (Marcuse, Begriff des Wesens, p. 68).

3 "Die Sorge um den Menschen tritt in das Zentrum der Theorie; er soll aus der wirklichen Not und dem wirklichen Elend zu sich selbst befreit werden” (Marcuse, Begriff des Wesens, p. 71).
} 
cannot be seen. The industrial and technological rationality has turned the subjects into appendages. It is marked by "pure instrumentality" and "efficacy” (Kellner, Herbert Marcuse, p. 234). Society itself is no longer primarily characterized by contradictions and conflicts. Each form of opposition is apparently neutralized or integrated by a coherent and overall structure of domination.

At first glance, therefore, in the One-Dimensional Man, we must face an extremely pessimistic diagnosis. A world run by bureaucracy and culture industry destroys the individuality of the subject, his/her private sphere, and manipulates his/her needs. However, Douglas Kellner (Herbert Marcuse, pp. 234ff.) has suggested that we would be misunderstanding Marcuse, if we followed this interpretation of total domination. Marcuse would in no way completely deny any possibility of contradiction, conflict, resistance or revolt.

In Marcuse's usage the adjective "one-dimensional” describes an epistemological distinction between signifying practices that conform to pre-existing structures, norms and behavior in thought and practice, and "bi-dimensional" thought which appraises values, ideas and behaviour in terms of possibilities that transcend the established state of affairs. (p. 235)

In late capitalism, there are also values, attitudes, ideas and behaviors that challenge the existing order. In this context, Raymond Williams spoke of emergent perceptions, perspectives and practices that can produce an oppositional or alternative culture: "It is true that in the structure of any actual society, and especially in its class structure, there is always a social basis for elements of the cultural process that are alternative or oppositional to the dominant elements” (p. 124). However, the one-dimensional man is bound in the dominant structure of feeling and is not interested in transforming the existing relations; he does not even consider this at all.

It is also important to put down that Marcuse describes and highlights bluntly and drastically the dominant tendencies of advanced industrial societies, its structures of domination and as a result its one-dimensionality. Nevertheless, Marcuse has not given up hope for change, as he makes clear in the essay, On Changing the World, for example. On the one hand, he sees the tendency of the system to hold radical, social forces back but on the other hand, he points to the desire of many to abolish the existing society and its structures. He feels the duty of the (socialist) intellectual is to analyze without illusion the reasons and possibilities for this. Marcuse states: "No social system is safe from change - that is an obvious truth, which should always be repeated" (qtd. in Tauber, p. 70).

The negative social diagnosis is therefore linked to a hope for global transformation and to a call for this.Zvi Tauber has shown that this is not a contradiction in Marcuse's theory but rather is anchored in the conditions of one-dimensional existence themselves (p. 72). At this point, it's necessary to point out that Antonio Gramsci also argued for a connection between the pessimism of intellectual social analysis and an optimism of the will. In more recent critical theory, Alain Badiou focuses on the "event" which is unforeseeable and more than the sum of the processes which have led to it. In a further step, I would now like to show that one-dimensionality proves be a useful category for a critical analysis of the present as well.

\section{One-Dimensionality and Neo-liberalism}

When we consider sociological diagnoses of the present, it is often stressed that in the West, we live in pluralistic societies that are apparently characterized by social and cultural differentiation, opportunities to make choices, individualization or a "reflexive project of the self" (Giddens, Modernity). In the process of globalization, we are confronted with processes of detraditionalization (Heelas et al.). Traditions are seen as 
losing their binding character, while, at the same time, we are confronted with a multiplicity of meaning systems, from which we can or have to choose. Sir Anthony Giddens establishes this at the beginning of the 21st Century: "We have good reason to hope that the cosmopolitan attitude will win the day. Tolerance towards cultural diversity and democracy belong together- and democracy is spreading everywhere across the world at present” (Entfesselte Welt, p. 15). At the same time, Ulrich Beck evoked the new "children of freedom" who would see themselves as actively engaged and would look for their own luck (Brave New World). Both authors accept and welcome the new possibilities of capitalism. Nevertheless, Beck—in contrast to Giddens—argues that a new critical theory from a cosmopolitan perspective is required to understand the new forms of social inequality in the global age und to develop counter-powers (Power). But he can't imagine a non-capitalistic world society.

A more radical analysis which is carried out principally from the two-dimensional thinking of the dialectics shows, however, that the economic organization of all parts of life presents a historically unmatchable homogenization according to the principals of the market, of competition, of efficiency and of reproducibility. ${ }^{4}$ This does not bar processes of heterogenization from being a part of it, for example, where the shaping of one's own life is concerned. Michael Hardt and Toni Negri rightly speak of a real subsumption of work and of all parts of life under processes of capital accumulation. "Capital has become a world. Use value and all the other references to values and processes of valorization that were conceived to be outside the capitalist mode of production have vanished” (p. 386).

Present existence is one-dimensional because market fundamentalism acts as a type of religion, which the whole world has embraced. It didn't only shape the economy but also politics, the health system, education, universities, all fields of society as well as our thinking (Freytag \& Zima, p. 53). For most, it is impossible to conceive of a society that isn't organized along market capitalist lines. Possible alternatives are also forgotten or discredited. Even advanced sociology of globalization celebrates the market and its possibilities. Without doubt, contemporary sociology that has turned away from philosophy and its two-dimensional thinking is generally characterized by a "paralysis of criticism” (Marcuse, One-Dimensional Man).

It seems therefore advisable to use Marcuse's concept of one-dimensionality for the analysis of the present, even if Western societies have changed many of the parameters that were important for Marcuse's analysis. Examples of this are the disappearance of the (old) East-West conflict, the growing destruction of the welfare state, life's increasing uncertainty that can be seen in mass unemployment and poverty among the young and elderly. The contemporary conditions are one-dimensional because there appears to be no alternative. From this background, the importance of critical theory and a dialectical thinking bound to determinate negation becomes clear. It can bring liberation from the social constraints of late capitalism and reveal emancipatory and utopian dimensions (Pippin). Jürgen Habermas, however, has declared the radical potential of critical theory in its first generation as old-fashioned and has tried to eliminate it (Theorie, vol. 1).

\section{Liberation and Understanding}

Habermas (Theorie, vol. 1) criticizes Horkheimer/Adorno for failing to clarify the principles of their own criticism in their analysis of instrumental rationality and its effects. In contrast, his Theory of Communicative Action is designed from the outset as a theory of rationality that can set out its critical rules. To that end,

\footnotetext{
${ }^{4}$ Neoliberalism can be interpreted as a form of counterrevolution, as Charles Reitz and Stephan Spartan show in The Political Economy of Predation and Counterrevolution.
} 
Habermas has made a paradigm change. He no longer analyses reason from the perspective of a theory of consciousness but on the basis of a theory of language and discourse. He is of the opinion that it is not justifiable from the view of social theory as rationality can be assigned to subjects. In contrast, the "linguistic turn" of philosophy can show that rationality can be found in the structures of linguistic understanding. "Linguistic understanding as a mechanism of co-ordinating action is the focus of interest" for a theory of communicative action" (Theorie 370; vol. 1). This means reaching an understanding is possible if the conditions are given that make actions inter-subjectively understandable.

Finally the concept of communicative action refers to the interaction of at least two subjects capable of speech and action who establish interpersonal relations [...] The actors seek to reach an understanding about the action situation and their plans of action in order to coordinate their actions by the way of agreement. The central concept of interpretation refers in the first instance to negotiating definitions of the situation which admit of consensus. (Communicative Action 86; vol. 1)

Linguistic understanding is reflexive and means validity claims must be justified. For Habermas, there is a rationality anchored in every day communicative practices that can be formally reconstructed through the reflexivity of validity claims. The actors have the capacity to act rationally and to make decisions in the context of given rules and available knowledge. In the concept of communicative rationality, understanding replaces reconciliation (Adorno) or liberation (Marcuse). For Habermas, we have surpassed thinking of the subject and its negating criticism. Instead, he has developed a formal process for reconstructing rules. However, this does not consider the content of communicative rationality under normative criteria. Therefore, it remains unclear how the communicative action of ascertained claims can lead to a critical theory (Thyen, pp. 253ff.).

At this point it becomes clear what we lose when critical theory focuses on understanding and the utopia of communicative rationality. It is the field of experience that plays a decisive role in the dialectics. The given state of affairs can be transcended by the subject who, in this way, can show resistance to the system. He/she is more than a cognitive and rational agent. He/she is an "embodied subject"with feelings, phantasies and desires(Farr 154ff.). For example, the "new sensibility" that Marcuse detected in the student movement of the 60ties was based on a new sensual and aesthetic experience of the self, of others and of nature with a utopian promise. Douglas Kellner summarizes this perspective in Marcuse's Essay on Liberation:

In Essay on Liberation, Marcuse argues that the cultural subversion contained in the new sensibility manifests in instinctual, moral and aesthetic revolt against the established society, leading to political rebellion [...] The revolt is generated by new needs and values which represent a break with the needs and consciousness of consumer society. (Kellner, Herbert Marcuse 341 and Marcuse and the Quest)

So negative dialectics is a material philosophy that takes into consideration the non-identical in experience. The non-identical cannot be precisely understood through the reconstruction of rules but it can be found in experiences. Therefore critical theory should not forgo experience that is conducted by theory or reflexion (Thyen, p. 269). Marcuse's and also Adorno's works show the rationality of knowledge based on negative dialectics, which isn't necessarily taken up in formally founded communicative rationality.

Therefore, the paradigm change demanded by Habermas does not seem to be required. We don't have to follow him. ${ }^{5}$ Rather, practicing critical theory today is about integrating both paradigms. In the works of

\footnotetext{
${ }^{5}$ Andrew Farr elaborates in his book Critical Theory and Democratic Vision that the approach of Habermas based on the ideal of a rational discourse cannot be considered as a theory of liberation. "First, it is overly restrictive of forms of discourse or communication. Second, it is overly restrictive with respect to its understanding of the formation of subjectivity. Third, it has a narrow view of the lifeworld. As a result of these limitations Habermas's theory is one-dimensional” (p. 151f.).
} 
Habermas, who is a convinced social democrat, we don't find a radical criticism of late capitalistic society as we do in Marcuse. He criticizes the colonisation of the lifeworld by system imperatives, but does not challenge the system itself, that is late capitalistic economy. The protests from Seattle to Occupy Wall Street have made clear that even today a radical criticism of capitalism exists based on the experiences of those involved.

\section{Radical Criticism of Neo-liberalism}

These Networks of Outrage and Hope, as Manuel Castells calls them, are organized, like global capitalism, on the basis of digital technologies and wireless networks. They seek to effect social change and to create a different world.

By engaging in the production of mass media messages, and by developing autonomous networks of horizontal communication, citizens of the Information Age become able to invent new programs for their lives with the materials of their suffering, fears, dreams and hopes. They build their utopian projects by sharing their experience. They subvert the practice of communication as usual by occupying the medium and creating the message. They overcome the powerlessness of their solitary despair by networking their desire. They fight the powers that be by identifying the networks that are. (Castells, p. 9)

The question that is asked is whether a qualitative change in late capitalistic society is not only imaginable, but even realizable by these form of resistances. From this background, the networks, above all, are interesting that challenge the one-dimensionality of corporate capitalism, seek for utopian alternatives and champion social justice.

At the end of the previous century, it seems there were no alternative to the one-dimensional, neo-liberal, organized society. The ideology of the free market, which was heralded incessantly in politics and the media, appeared to have finally been accepted generally. Bit by bit, but firstly in the Global South, a counter movement arose which was still unnoticed by many, until it became spectacularly visible for the first time in the protests and mobilizations against the meetings of the World Trade Organization in November 1999 in Seattle. To date, plenty of protests have come together against globalization as defined by corporations and which support democratically shaped alternatives (Kahn and Kellner; Juris).

Symbolically successful resistance against corporate capitalism does not only take place on the streets but primarily by means of digital technologies. Therefore, the evolving networks of activists are both locally anchored and globally interconnected. This interactive character promotes autonomy, open access and horizontal co-operation. Therefore, a protest can grow easily; it can be deliberated on and modified. In this way, resistance, participation and direct democracy can be experienced, practiced and lived. Now it becomes possible once more to imagine a utopian world that is organized according to ideals of social justice and equality (Smith). The late capitalistic reality, which is propagated without alternatives by politicians, scientists and the mass media, is fundamentally challenged and opposed.

The new social movements create counter public spheres that are based on social networks online and offline. Therefore, movements have a viral character, which, above all, Occupy has shown. Starting from New York, this has given rise to spaces for protest across the world. These are organized horizontally and create a social bond by common experiences and practices, which can be disrupted quickly but can potentially be re-established again and again. Socially institutionalized domination meets a counter power of (digital) resistance from the new social movements. Autonomous communication networks arise in which new outlooks and utopian concepts for life and society are developed and approved together. 
We have seen that Marcuse in his analysis of one-dimensional society could not identify concrete tendencies or forces that negated this state of affairs and would remodel it in a revolutionary practice. "Confronted with the total character of the achievements of advanced industrial society, critical theory is left without the rationale for transcending this society" (One-Dimensional Man xlvi). However, he thinks this transcendence is necessary and so hopes for it. "In the face of apparently contradictory facts, the critical analysis continues to insist that the need for qualitative change is as pressing as ever before" (xlv). Marcuse therefore does not exclude the possibility for change. Throughout his life, he was searching for social and cultural forces of negation.

Thus, in his writing after One-Dimensional Man, for example, in An Essay on Liberation, he closely examined and welcomed the potential for liberation in the 60s. In the students, however, he saw no revolutionary force but hoped that they could act as catalysts in their criticism and their protest. The digital activism of our time also reacts against the assimilating and integrating powers of one-dimensional capitalism. Has a real opportunity arisen here that can immanently negate and transform the established society? From the background of Marcuse's theory, scepticism is appropriate. The forces of state authority and of ideological as well as commercial incorporation are not rated highly enough. A radical social change is only then possible when this critique of corporate capitalism is taken up, shared and practiced by many. Nevertheless, this rebellious protest shows that the late capitalistic system is not monolithic and closed. Activists challenge its legitimacy. They believe in a different world and show in their networks that this utopian condition, that is the negation of what is, is more than a dream (Juris, p. 9). Finally, I would like to look more closely at the field of aesthetics. According to Marcuse, imagination allows, above all, transcendence of the given society and the imagining of a different world.

\section{Art and Revolution}

In his article, Art in the One-Dimensional Society, Marcuse writes: “[...] the survival of art may turn out to be the only weak link that today connects the present with the hope of the future” (p. 54; qtd. in Reitz, p. 166). He states that a new reality can be realized by means of art: "Not political art, not politics as art, but art as the architecture of a free society.”(p. 65f.; qtd. in Reitz, p. 170). Marcuse continues by stating that art can convey new forms of perception and understanding that let us discern and experience social reality differently and preserve the hope for the utopia of liberation (p. 79). Thus he also stresses here and in his last book, The Aesthetic Dimension, the important significance and active power of the aesthetic form, which should be materialized in society itself. Marcuse states that the quality of the aesthetic form reveals the political potential of art (Aesthetic ix). It transcends the existing repressive society and subverts its dominant framing of reality. It establishes its own reality principle. The fictitious world of art becomes the real reality.

Its indictment of the established reality and its invocation of the beautiful image ("schöner Schein") of liberation are grounded precisely in the dimensions where art transcends its social determination and emancipates itself from the given universe of discourse and behavior while preserving its overwhelming presence. Thereby art creates the realm in which the subversion of experience proper to art becomes possible: the world formed by art is recognized as a reality which is suppressed and distorted in the given reality. (p. 6)

For Marcuse the aesthetic form itself carries meaning that transcends the given state of affairs and reasserts the utopian possibility. The experience of art can transform the subjectivity of recipients by liberating it from social constraints and norms. Finding its own inner voice, articulating its "inner history" (p. 5), its 
“Eigensinn” (Winter, Kunst), can prepare for processes of changing culture and society (Marcuse, Aesthetic, p. 32f.).

In a situation where the miserable reality can be changed only through radical political praxis, the concern with aesthetics demands justification [...] it seems that art as art expresses a truth, an experience, a necessity which, although not in the domain of radical praxis, are nevertheless essential components of revolution. (p. 1)

Marcuse states that, through its emancipatory potential, art negates the conditions of one-dimensionality and points out to that utopian condition that stands beyond the oppression of the given order. Charles Reitz comes in his comprehensive study on the development of Marcuse's aesthetics to the conclusion:

In Marcuse's estimation, the aesthetic dimension presents the emancipatory image of the social potential of the human species at the same time as it presents a depiction of factual human distress. The subject matter of genuine historical study is the highly conflicted sensuous and affective essence of humanity. The foundation of Marcuse's protest and the basis of his recommended political activity against the one-dimensional society is his theory of aesthetic negation. (p. 226)

In the following I will show how relevant and of current interest these considerations of Marcuse are in the works of the French philosopher Jacques Rancière on the Politics of Aesthetics, which are currently being intensively discussed.

For Rancière as well the political can also emerge from aesthetic practices. He thinks that the space is constituted through a distribution of the sensible, of the visible and sayable. Following Schiller and Kant, he sees the political meaning of art in modernity in the fact that it can produce a redistribution of the sensible by a Dissensus (pp. 115ff.). It can fabricate new objects and new forms of perception that do not occur in the everyday framings of the world. Art creates a counter-world that challenges the order of a given society and thereby steps into a polemic relationship with the existing world. Therefore, Rancière attributes an active force to art. It produces a dissensus when the parameters of our sensible world are unsettled and transcended. Then, this world is not only experienced differently but also structurally transformed. The aesthetic revolution consists precisely in radically changing the meaning of life.

Like Marcuse, Rancière draws on Friedrich Schiller's reflections On the Aesthetic Education of Man. "We could reformulate this thought [of Schiller] as follows: there exists a specific sensory experience that holds the promise of both a new world of Art and a new life for individuals and the community, namely the aesthetic" (Rancière, Dissensus, p. 115). Art contains the political promise of equality and an aesthetic form of life that is dissensual to everyday experiences of the world. Through the form of art, which reveals new dimensions and perspectives, the distribution of the sensible, which according to Rancière is controlled by the police order in modernity, is challenged. At the same time, equality is created between producers and recipients in the aesthetic regime.Even the recipient is creative. As spectator he/she is emancipated. He/she reflects on art and simultaneously articulates equality.

Rancière does not refer to Marcuse. According to his own testimony, he discovered Schiller's letter on the aesthetic education by chance in a Parisian second-hand-bookshop (Rancière, Méthode, p. 137). Nevertheless, his works shows why Marcuse's reflections on the political meaning of aesthetics have lost none of their relevance today. Art is another form of reality and contains a revolutionary promise (Reitz; Miles, pp. 126ff.). "Art represents the ultimate goal of all revolutions: the freedom and happiness of the individual" (Marcuse, Aesthetic, p. 69). 


\section{Concluding Remarks}

Throughout his life, Herbert Marcuse did not give up his belief in the revolution, in utopia and in the liberation of humanity. Without illusions, he revealed the processes and mechanisms that successfully prevented emancipation. Nonetheless, he staunchly believed in radical social change. He never accepted the one-dimensionality of the present but was of the opinion, that theory, art and social movements can testify to the multiplicity of our existence, contain the promise of utopia and reveal alternatives. Even when Marcuse declares in One-Dimensional Man that in late capitalism, domination is increasing and no alternative can be found to deny and overcome the system, he considered it his duty and purpose to champion change and liberation. This accounts for the continued fascination and the power of his critical theory that points to the future and its utopian possibilities. Therefore we should return to Marcuse's critical theory and think again about his philosophy of emancipation and utopia and connect it to the struggles of the present.

\section{References}

Badiou, A. (2013). Philosophy and the event. With Fabien Tarby, Polity Press.

Beck, U. (2000). The brave new world of work. Polity Press.

Beck, U. (2005). Power in the global age: A new global political economy. Translated by Kathleen Cross, Polity Press.

Castells, M. (2012). Networks of outrage and hope: Social movements in the internet age. Polity Press.

Farr, A. (2009). Critical theory and democratic vision: Herbert Marcuse and recent liberation philosophies. Lexington Books.

Freytag, T. (2008). Der unternommene Mensch: Eindimensionalitätsprozesse in der gegenwärtigen Gesellschaft. VelbrückWissenschaft.

Giddens, A. (1991). Modernity and self-identity: Self and society in the late modern age. Polity Press.

Giddens, A. (1999/2001). Entfesselte Welt: Wie die Globalisierung unser Leben verändert. Suhrkamp.

Gramsci, A. (1971). Selections from the prison-notebooks. Translated and edited by Quentin Hoare and Geoffrey Nowell-Smith, Lawrence \& Wishart.

Habermas, J. (1981). Theorie des kommunikativen Handelns. 2 vols. Suhrkamp.

Habermas, J. (1984). Theory of communicative action. 2 vols. Translated by Thomas McCarthy, Beacon Press.

Habermas, J. et al., editors. (1978). Gesprächemit Herbert Marcus. Suhrkamp.

Hardt, M., \& Negri, T. (2000). Empire. Harvard University Press.

Heelas, P. et al., editors. (1996). Detraditionalization. Blackwell.

Horkheimer, M., \& Theodor, W. A. (1947/1972). Dialectic of enlightenment. Herder and Herder.

Juris, J. S. (2008). Networking futures: The movement against corporate capitalism. Duke University Press.

Kahn, R. and Kellner, D. (2005). Internet subcultures and political activism. Cultural studies: From theory to action, edited by Pepe Leistyna, Blackwell.

Kellner, D. (1984). Herbert Marcuse and the crisis of Marxism. University of California Press.

Kellner, D. (2004). Marcuse and the quest for radical subjectivity. In J. Abromeit and W. Mark Cobb (Eds.), Herbert Marcuse: A critical reader (pp. 81-99). Routledge.

Marcuse, H. (1936). Zum Begriff des Wesens. In Herbert Marcus (Ed.), Schriften Band 3: Aufsätze aus der Zeitschrift für Sozialforschung (pp. 45-84). Zu Klampen.

Marcuse, H. (1969). An essay on liberation. Beacon Press.

Marcuse, H. (1973). Art in the one-dimensional society. In Lee Baxandall (Ed.), Radical Perspectives in the Arts. Penguin.

Marcuse, H. (1978). The aesthetic dimension: Towards a critique of Marxist aesthetics. Beacon Press.

Marcuse, H. (1964/1991). One-dimensional man: Studies in the ideology of advanced industrial society (2nd ed.). With an Introduction by Douglas Kellner, Beacon Press.

Marcuse, H. (1967). On changing the world: A reply to Karl Miller. Monthly Review, 19(5), 42-48.

Miles, M. (2012). Herbert Marcuse: An aesthetics of liberation. Pluto Press.

Pippin, R. et al., editors. (1988). Critical theory and the promise of utopia. Macmillan Education.

Rancière, J. (2004). The politics of aesthetics. Translated by Gabriel Rockhill, Continuum.

Rancière, J. (2010). Dissensus: On politics and aesthetics. Translated and edited by Steven Corcoran, Continuum. 
Rancière, J. (2012). La méthode de légalité: Entretien avec Laurent Jeanpierre et Dork Zabunyan. Bayard Editions.

Reitz, C. (2000). Art, alienation, and the humanities: A critical engagement with Herbert Marcuse. State University of New York. Reitz, C., \& Spartan, S. (2013). The political economy of predation and counterrevolution. Recalling Marcuse on the radical goals of socialism. In Charles Reitz (Ed.), Crises of Commonwealth. Marcuse, Marx, McLaren (pp. 19-42). Lexington.

Schiller, F. (1795/1965). On the aesthetic education of man in a series of letters. Ungar.

Smith, J. (2008). Social movements for global democracy. The John Hopkins University Press.

Tauber, Z. (1994). Befreiung und das "Absurde”: Studien zur Emanzipation des Menschen bei Herbert Marcuse. Bleicher Verlag. Thyen, A. (1989). Negative Dialektik und Erfahrung: Zur Rationalität des Nichtidentischen bei Adorno. Suhrkamp.

Williams, R. (1977). Marxism and Literature. Oxford University Press.

Winter, R. (2001). Die Kunst des Eigensinns: Cultural Studies als Kritik der Macht. Velbrück Wissenschaft.

Winter, R. (2010). Widerstand im Netz: Zur Herausbildung einer transnationalen Öffentlichkeit durch netzbasierte Kommunikation. Transcript.

Winter, R. (2010). The perspectives of radical democracy: Raymond Williams’s work and its significance for a critical social theory. In Monika Seidl et al. (Eds.), About Raymond Williams (pp. 45-56). Routledge.

Zima, P. V. (2015). Entfremdung: Pathologien der postmodernen Gesellschaft. A. Francke/utb. 